\title{
THE REDUCTION OF COMA TIME IN LIPOPHILIC DRUG OVERDOSE USING CASTOR OIL
}

\author{
M.J. Diamond, Y.S. Brownstone, G. Erceg, H. Kieraszewicz, and \\ M. KeERI-Szanto*
}

Is 1951 Nilsson ${ }^{1}$ revolutionized the treatment of drug overdosage by introducing supportive therapy and thereby reduced mortality from 25 per cent to 2 per cent.

Since that time, our attention has been directed towards eliminating the drug as rapidly as possible, since length of coma bears a close relationship to complication rate, the most common of which is respiratory tract infection.

Diuresis $^{2}$ and dialysis ${ }^{3}$ are efficient methods of eliminating water soluble drugs from the circulation. Adsorption techniques are also effective measures. ${ }^{4,5}$

There remains, however, a problem group of drugs which are strongly lipophilic - Ethchlorvynol, Glutethimide, Methyprylon and Methaqualone. These drugs produce lengthy coma and by their physical nature are poorly water soluble and therefore do not respond well to measures which rely on aqueous solution. ${ }^{6-8}$ In fact, forced diuresis is contraindicated because not only does one see obvious signs of oedema in the conjunctivae, skin and lungs but cerebral oedema also occurs and will serve to further confuse the neurological picture. In one case of Ethchlorvynol poisoning we saw bilateral retinal detachments. At this time there is no satisfactory explanation for the mechanism of this oedema.

Castor oil has been used to gavage patients with lipophilic drug overdosage and anecdotal reports have been favourable. Nurses report messy beds for a shorter time!

Bowel sounds disappear in deep coma and it is suggested that unabsorbed drug may remain in the gastro-intestinal tract at this time. ${ }^{9}$

Castor oil may act as a ligand as well as a cathartic and prevent unabsorbed drug from leaving the gastro-intestinal tract.

In an attempt to substantiate these possibilities, patients with lipophilic drug overdosage were given approximately $500 \mathrm{ml}$ castor oil by nasogastric tube every twelve hours during coma in addition to the appropriate supportive therapy. The response to this treatment was not one of overwhelming enthusiasm by the nursing staff until they were convinced that patients woke up sooner. The response of the medical staff varied from mild disdain to abject horror.

Therefore an experimental study was undertaken to confirm that castor oil acts as a ligand and also that its use reduces coma time in Ethchlorvynol poisoning.

\section{Method and Material}

Experiment 1. To establish the ligand effect, five dogs were given $150 \mathrm{mgm}$

'From the Departments of Anaesthesia and Clinical Biochemistry, University of Western Ontario, Victoria Hospital, London, Ontario. 


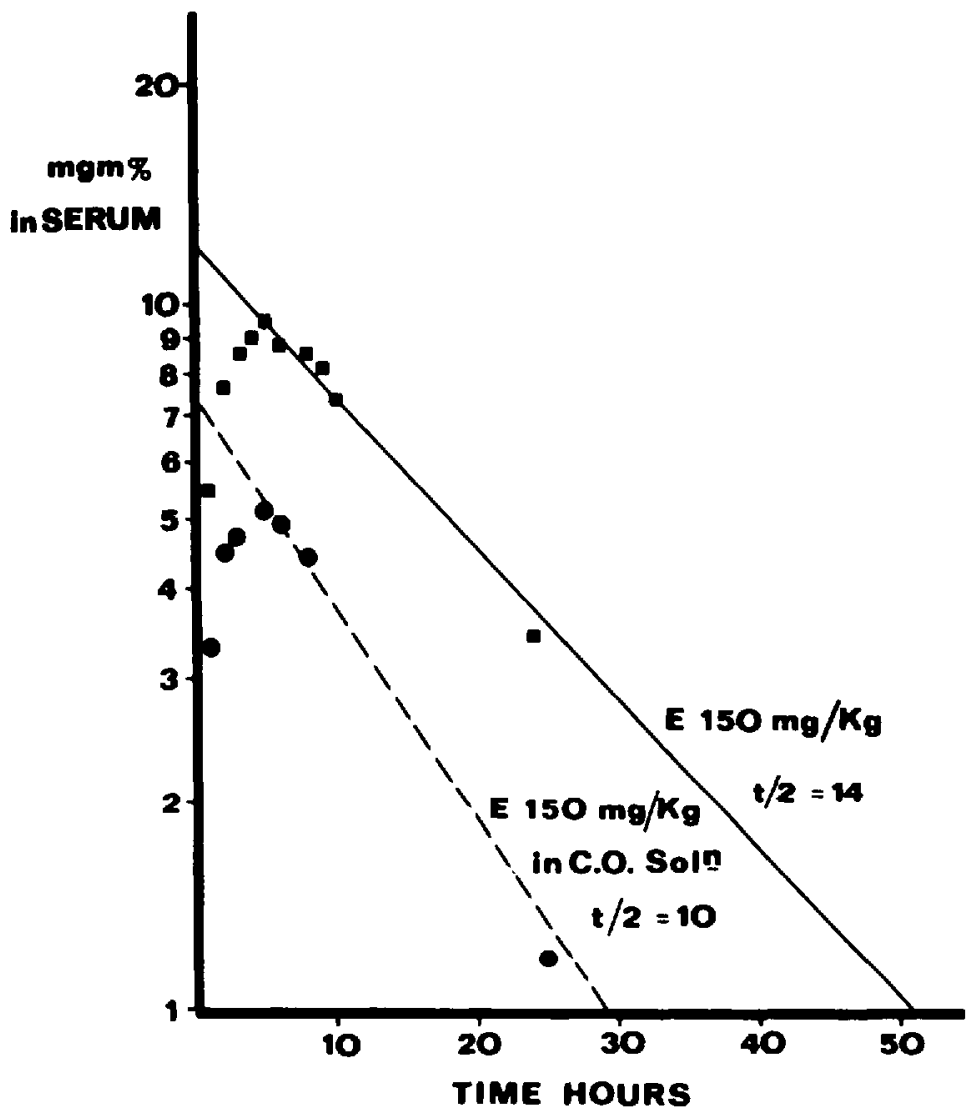

Figure 1. Serum Ethclorvynol levels following administration of $150 \mathrm{mg} / \mathrm{kg}$ in capsule by mouth or dissolved in castor oil. Ordinate: serum concentration on logarithmic scale. Abscissa: elapsed time. In this form, the exponential decay of the drug (Beta phase) defines a straight line. Each curve represents average data from five dogs.

Ethchlorvynol $/ \mathrm{kg}$ body weight both plain and in castor oil solution, the dose of castor oil being $10 \mathrm{ml} / \mathrm{kg}$.

This was done in crossover fashion so that each dog became its own control. These dogs were treated as we treat patients with drug overdosage in the Intensive Care Unit and when appropriately in coma were intubated and artificially ventilated until such time as they no longer tolerated the tracheal tube. They also had appropriate intravenous therapy. The observed fall in body temperature was obtunded by infrared heat lamps. The appropriate cuff drill and tracheobronchial toilet were carried out and position was changed two-hourly. Serial serum concentrations were obtained by the method described by Frings and Cohen. ${ }^{10}$ The results are shown in Figure 1.

Experiment 2 was designed to more closely mimic the clinical situation, in that castor oil was given at the same relative point in time of coma as it would be administered to a patient.

Ten crossover experiments were performed with the Ethchlorvynol dose in- 


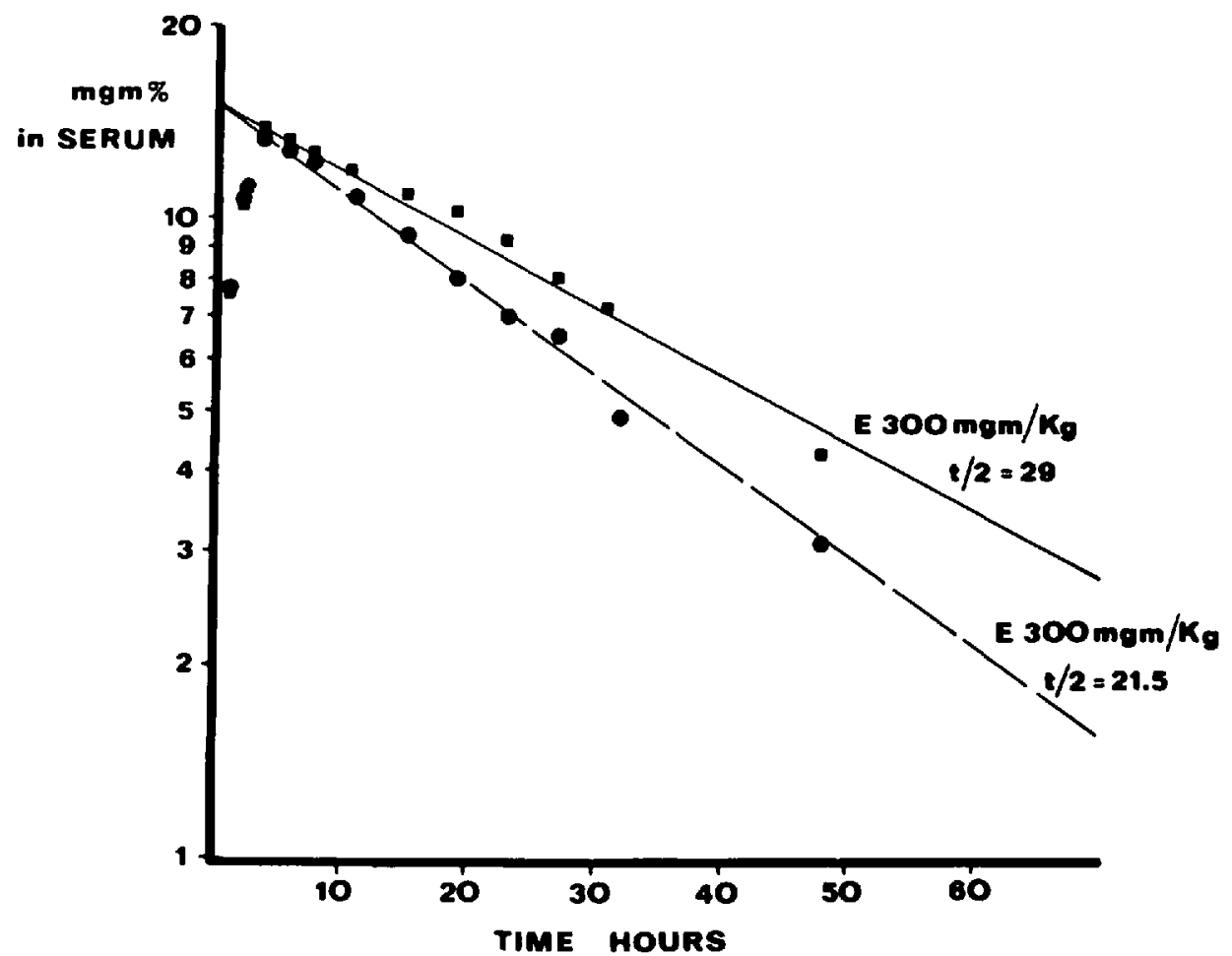

FIGURE 2. Ethchlorvynol concentration in serum following the oral administration of 300 $\mathrm{mg} / \mathrm{kg}$. The continuous line represents the controls. The broken line represents the treatment group when $15 \mathrm{ml} / \mathrm{kg}$ castor oil was administered one hour later and $\mathrm{q} 12 \mathrm{~h}$. The correlation coefficient $(R)$ of the two curves is 0.98 and 0.96 respectively and the difference between the Beta slopes is significant at the 0.01 per cent level.

creased to $300 \mathrm{mg} / \mathrm{kg}$ in order to extend the coma time and the castor oil dose increased to $15 \mathrm{ml} / \mathrm{kg}$. Serial blood estimations were repeated as before and plotted in the same way. The results are shown in Figure 2.

\section{Discussion}

The important points in Figure 1 are, first, that peak serum levels were reduced where the castor oil solution was employed but they occurred at approximately the same time and this suggests a ligand effect. Second, that the slopes of decay differ in that the half-life for Ethchlorvynol is 14 hours and for the castor oil solution is 10 hours. The clinical significance of this is doubtful.

The curves in Figure 2 do not show a ligand effect but do show a significant decrease in drug half-life of the same general order as the first set of figures. The drug half-life at different dose levels should not change as long as a single inactivating mechanism operates. The fact that we find here a lengthening of the half-life in the serum with increasing dosage, suggests that Ethchlorvynol is inactivated by an easily saturated, rapidly acting mechanism and also by a slower mechanism that has a much greater capacity. 


\section{METHYPRYLON COMA}

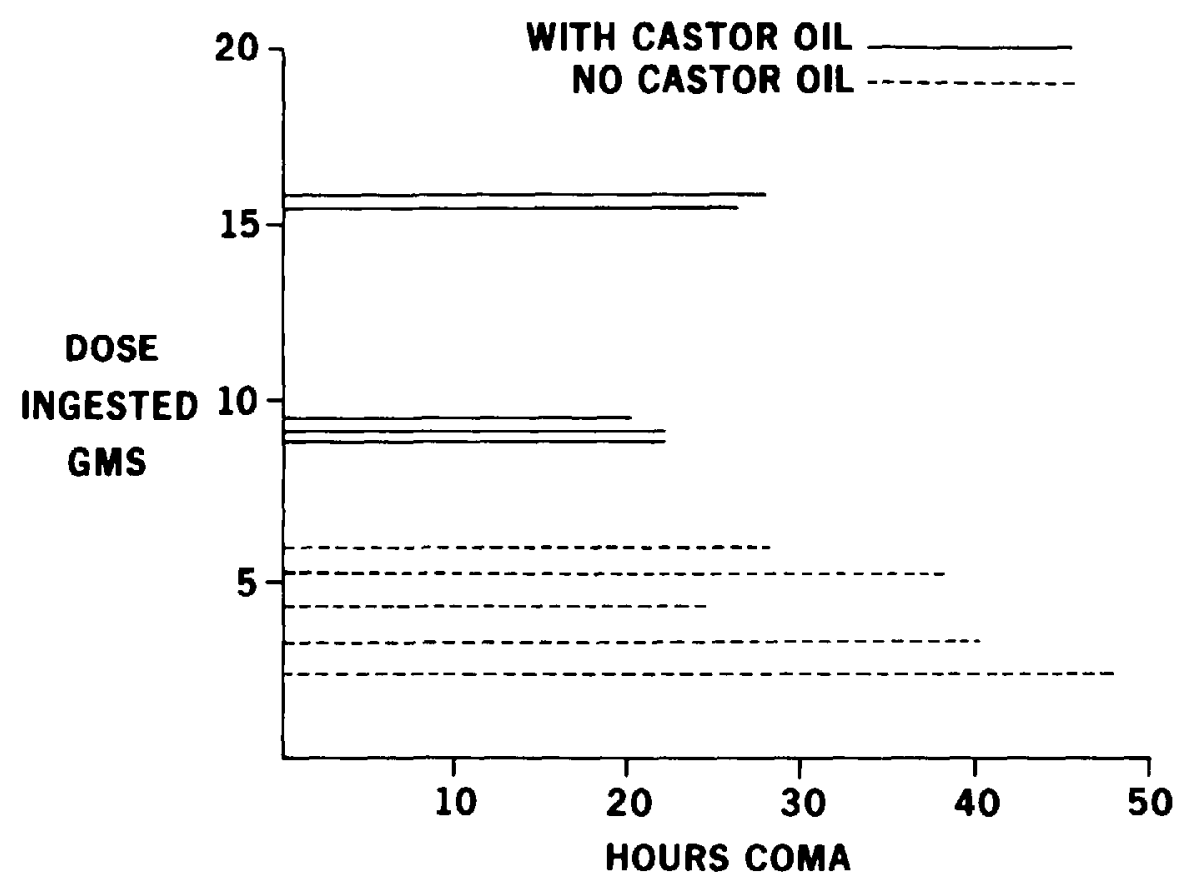

Figure 3. The relationship between the ingested drug dose and coma time in human drug overdose with Methyprylon. Broken lines represent patients treated with conventional supportive therapy. Continuous lines indicate the addition of castor oil to the treatment regimen.

It would appear that the effective dose level in the first experiment is reduced by the ligand effect of castor oil.

The second experiment, on the other hand, shows identical intercepts and identical peak levels and some additional explanation for reduction in half-life is required. The data suggests the possibility that castor oil in this case increases the effective distribution space and that Ethchlorvynol may well diffuse from the circulation into the castor oil in the bowel lumen. We are presently investigating this hypothesis.

\section{Clinical Observation}

A retrospective study was done to compare the course of two groups of five patients each who had ingested an overdose of a lipophilic drug and had been treated similarly except for the addition of castor oil to the treatment regimen. The results are shown in Figure 3.

The results shown in Figure 3, which deal with Methyprylon overdose, indicate that castor oil treatment of patients is even more effective than the dog studies done in Figure 2 would indicate. The shortening of coma time is clinically highly significant. We therefore recommend the use of castor oil in cases of lipophilic drug overdose in view of the foregoing. 


\section{SUMMARY}

A clinical trial of castor oil in overdoses of lipophilic drugs gave a strong clinical impression that it was effective in speeding up recovery. Therefore, animal experiments were undertaken to confirm that castor oil acts as a ligand in Ethchlorvynol poisoning and that its use reduces coma time.

Serial serum levels of Ethchlorvynol were obtained from dogs given Ethchlorvynol $150 \mathrm{mg} / \mathrm{kg}$ alone, and the same dose dissolved in castor oil $15 \mathrm{ml} / \mathrm{kg}$ in a crossover fashion. The result was a reduction of peak serum levels and of the halflife of the drug when the castor oil solution was used.

In order to mimic the clinical situation more closely, a further crossover study was undertaken using Ethchlorvynol $300 \mathrm{mg} / \mathrm{kg}$ alone and the same dose followed by castor oil $15 \mathrm{ml} / \mathrm{kg}$ repeated $\mathrm{q} 12 \mathrm{~h}$. This showed no delay in reaching peak serum concentration and no reduction of peak levels. However, it did show a 31 per cent reduction in the half-life of the drug. This change is statistically significant, and supports the continued use of castor oil in lipophilic drug overdose.

\section{RÉSUMÉ}

Un essai clinique de l'huile de castor dans le traitement des intoxications par surdoses d'agents lipophiliques avait laissé l'impression que cet agent abrégeait le temps de récupération. Ceci nous a amené à faire l'essai de cet agent chez l'animal afin d'évaluer sa capacité à lier l'Ethchlorvynol pour ainsi raccourcir la durée du coma.

L'on a obtenu par prélèvements sériés les taux sériques d'Ethchlorvynol chez des chiens ayant reçu cet agent à la dose de $150 \mathrm{mg} / \mathrm{kg}$ lors d'une première expérience et, dans un deuxième temps, la même dose dissoute dans l'huile de castor à raison de $10 \mathrm{ml} / \mathrm{kg}$. Les taux sériques maxima ont été plus petits chez les chiens ayant reçu l'huile de castor; la demivie de l'Ethchlorvynol a été plus courte également dans le deuxième groupe.

Dans le but de simuler davantage les situations cliniques, une seconde série d'expériences a été entreprise, utilisant cette fois l'Ethchlorvynol à une dose de $300 \mathrm{mg} / \mathrm{kg}$ avec répétition aux 12 heures de la même dose suivie d'huile de castor à la dose de $15 \mathrm{ml} / \mathrm{kg}$.

On n'a pas observé dans ces cas de retard à atteindre les taux sériques maxima et ces mèmes maxima n'ont pas été réduits. Cependant, on a trouvé une réduction de 31 pour cent de la demi-vie de l'Ethchlorvynol. Ce résultat statistiquement significatif confirme l'utilité de l'huile de castor dans le traitement de la surdose en agents lipophiliques.

\section{REFERENCES}

1. Nilsson, E. On treatment of barbiturate poisoning. Acta. Med. Scand. 139: Supp. 253 (1951).

2. Linton, A.L., Luke, R.G., \& Briggs, J.P. Methods of forced diuresis and its application in barbiturate poisoning. Lancet 2: 377 (1967).

3. Schreiner, G.E. \& Teehan, B.P. Dialysis of poisons and drugs. Trans. Am. Soc. Artif. Intern. Organs, 17:513 (1971). 
4. Ruedy, J. Acute drug poisoning in the adult. C.M.A.J. 109: 603 (1973).

5. Chang, T.M.S., Coffey, J.F., Barre, P., Gonda, A., Dirks, J.H., Levy, M., \& Lister, C. 'Microcapsule artificial kidney. C.M.A.J. 108: 429 (1973).

6. Hansen, P.R., Kennedy, K.A., Ambre, J.J., \& Fischer, L.J. Glutethemide poisoning. N.E.J.M. 292: $250(1975)$.

7. Teeman, B.P., Maher, J.F., \& Carey, J.J.H. Acute ethchlorvynol intoxication. Ann. Inter. Med. 72: 875 (1970).

8. Yudis, M., Swartz, C., Onesti, G., Ramirez, O., Snyder, D., \& Brest, A. Haemodialysis for methyprylon poisoning. Ann. Inter. Med. 68: 1301 (1968).

9. Waight, R.C. A simple plan for the management of drug overdose. Anaesth. Intens. Care. $2: 288(1974)$.

10. Frings, C.S. \& Cohen, P.S. Rapid colorimetric method for the quantitative determination of Ethchlorvynol (Placidyl) in serum and urine. Am. J. Clin. Path. 54: 833 (1970). 